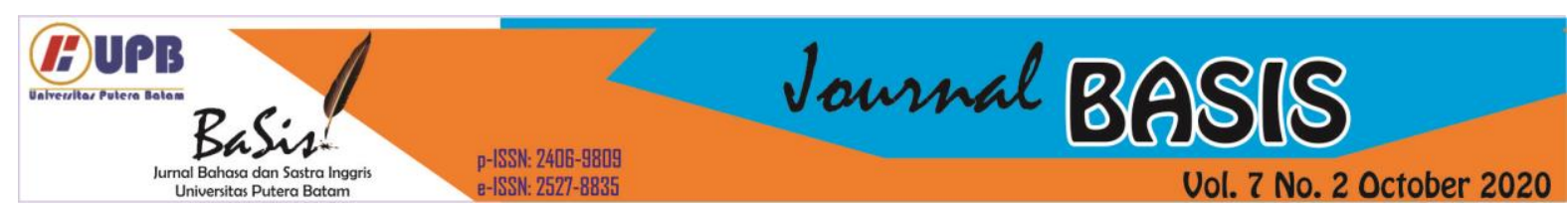

\title{
MANGO TREE'S DESIRE IN THE STORY OF DENGAR KELUHAN POHON MANGGA: STUDY ON PSYCHOANALYSIS OF LACAN
}

\author{
Devi Cintia Kasimbara \\ Universitas PGRI Madiun, Madiun, Indonesia \\ dkasimbara@gmail.com.
}

\begin{abstract}
Dengar Keluhan Pohon Mangga (DKPM) is the story written by Maria Amin during the Japanese colonial era. The author uses the metaphor of "mango tree" to escape Japanese censorship to be published so that there are many hidden meanings in this short story. This study aimed to determine the author's unconscious condition through the language used by using Lacan's psychoanalytic theory. This study used a qualitative research method with a poststructuralism approach using Lacan's psychoanalysis. The data source of this research is a document, namely the short story DKPM by Maria Amin. The sampling technique used purposive sampling. In this study, the data were obtained through document analysis, and then the data were analyzed according to Lacan's psychoanalytic theory, which begins by describing the life of the author - in this case, is Maria Amin - to understand his work. After that, he explained the characters of the characters in the DKPM short stories. Furthermore, the analysis was focused on the short stories' language, which can be seen through the metaphor and metonymy phenomena in this short story. In this way, it will be seen how the author's subconscious is filled with a sense of lack and loss, so that the desire to cover up the deficiency appears. The results showed that the short story DKPM is a short story that reflects the writer's unconscious condition. It can be seen in the short stories he wrote that the Indonesian nation was expressed metaphorically by using the word "mango tree", the Japanese nation as "areca tree", and the Dutch nation as "the man". In this short story, the mango tree (the Indonesian nation) is on lacks condition. So that there is a desire to gain recognition for its existence as a subject.
\end{abstract}

Keywords: Dengar keluhan pohon mangga; lacan; maria amin; psychoanalysis.

\section{INTRODUCTION}

Human life is driven by desire. Humans, from birth to escape from existential units in the Real-world, always experience a lack, humans are considered to be forever hollow. From birth to escape from existential units in the Real-world, humans still experience a lack, humans are considered forever hollow. A sense of deprivation forever follows like a ghost that haunts human life. Even though nobody can found this existential unity (in "the real" world). The feeling that is languished in this unconscious realm gives birth to an insatiable desire (Manik, 2016).

To see the desire in literature can use Lacan's psychoanalytic theory. All human actions result from desire so that the author's actions to produce literary works can be called a manifestation of the author's desire. In Lacan's sense, the author is such a deficient subject. Lacan's theory of the subject is that humans are represented by language, by unique objects called "words". The Lacan technical term for "word" is "signifiant". Whenever a person speaks 
or writes, he always manifests himself in language, with "signifiant". "Signifiants" are the only way the subject can manifest it self (Hill, 2002). Likewise with literature, which is a "signifiant" as a manifestation of the author's self.

Understanding literary works from a Lacanian perspective is an act to find a subconscious condition filled with feelings of inadequacy and loss accompanying the desire for unity above. For literary reviewers, the unconscious condition is a condition that cannot be fully accessed so that the understanding of literary works is directed to what happens to the language in the literary work, the extent to which the literary language comes out of it, through the metaphor and metonymy phenomena that exist in the literature (Faruk, 2012).

One of the literary works that describe the author's unconscious condition is the short story of Dengar Keluhan Pohon Mangga (DKPM) by Maria Amin, which was written during the Japanese colonial period. Maria Amin was born in 1921 in Bengkulu (Rosidi, 2013). She is one of the women writers who belonged to the 45th generation, to be precise, during the Japanese colonial period. At that time, there were many works of Indonesian writers who opposed Japan because of their disappointment with Japan.

In the Japanese colonial era, not many literary works were born. Several works were published during this time, but several other works could only be published after the proclamation of independence. The strictness of Japanese censorship made writers have to be good at racking their brains and making their works so symbolic that they could escape Japanese censorship. One of the authors who helped enliven Indonesian literature in this era is Maria Amin. Some of his works escaped Japanese censorship and were successfully published in Panji Pustaka, but some of his works did not pass.

Some of Maria Amin's literary works that were born during this period are Kapal Udara; Aku Menyingkir; Kekasihku Semua; Dengar Keluhan Pohon Mangga; Penuh Rahasia; and Tuan, Turutlah Merasakan. One of them is the short story Dengar Keluhan Pohon Mangga. DKPM is a literary work that was born as a form of disappointment with Japan. In this short story, the author tries to write down what he wants to convey through metaphors and metonymy in this short story.

Through the metaphor of "mango tree", the author describes the mango tree as a tree that experiences suffering during its growth process. The mango tree is in such a state of deprivation that it arises its desire for self-existence. This study aims to describe the author's unconscious condition through the metaphor of "mango tree" to cover shortcomings and find his identity again. All can be seen through the language in $D K P M$ 's short stories, and how they interact metaphor and metonymy phenomena. This author's unconscious condition can be seen through the language in DKPM's short stories, the extent to which metaphor and metonymy phenomena are in it.

\section{LITERATURE REVIEW}

\section{Lacan Psychoanalysis}

Lacan's psychoanalytic theory is a poststructuralism theory. Lacan's psychoanalytic theory is built based on Freud's theory (Ratna, 2011). One of the differences between Freud and Lacan's theory is that Freud views Ego as the essential element, while Lacan views language as having a primary psychoanalytic theory. (Sarup, 2011) reveals that Lacan's psychoanalytic theory is partly based on structural linguistics and anthropology. One of 
these theories is that the unconscious is a hidden structure similar to language. Knowledge of self, other people, and the world is determined by language. Language is a precondition for action to become aware that we are a distinct entity. The "me-you" dialectic that defines the subject in opposition to one another, which creates subjectivity. The language is also a social, cultural, prohibited, and legal given bearer. A child will be conditioned and shaped by language without being aware of the process. That can be understood through the fort/da child's play. In this game, the distance between self and real-life occurs in two stages. Namely, the child moves to leave his mother to get a spooler and finally to language.

The self-recognition is called Lacan as the mirror stage, which occurs at about six to eight months. In the first stage, when a child stands in front of the mirror with an adult, he will mix his image with the person's appearance image beside him. Second, children learn about the concept of images so that they finally realize that the image in the mirror is not real. Third, the child realizes that the mirror's image is his image and different from other images.

Lacan sees what is known as the Oedipus Complex as an axis of humanization, as a transition from a natural register to a group exchange register, and hence laws, language, and organization (Faruk, 2012). In the early stages, the child does not only want to connect with the mother and her affection but may unconsciously want the child to complete what is lacking in the mother, namely the phallus. At this stage, the child is not a subject, but something that is lacking, nothing. In the second stage, the father intervenes by seizing the object of the child's desire from the mother's physical object. The third stage is the stage of identifying the father figure. The father returns the phallus as the object of the mother's desire and no longer as the child's complement to what the mother lacks. It is the price a person has to pay if he is to be fully himself. According to Lacan, the Oedipus complex is a moment where children humanize themselves by realizing themselves, the world, and others.

The unconscious has a structure similar to language. Even Lacan said that language is a condition for the unconscious that language creates and generates the unconscious. According to Lacan, unconsciousness appears in the form of dreams, jokes, tongue sprains, and symptoms. Like conscious discourse, the unconscious (goals, etc.) says something different from what it seems to be conveying. These formations are regulated by the same mechanisms that govern language, namely metaphor and metonymy.

According to (Manik, 2016), metaphor and metonymy are the two main types of negotiations on markers. In Lacan's thought, metonymy is concerned with now these markers connect with other characteristics in a chain and, ultimately, with the whole network providing the pathways through which identification and desire work. Metonymy is a function by which discourse forms alliances and contradictions in these markers (Bracher, 2009).

\section{a. Self and Language}

Lacan connects his language theory with subjectivity. According to (Sarup, 2011) Lacan believes that the human subject cannot exist without language, but the issue cannot be reduced to language. The two of them have a circular relationship. Lacan argues that humans cannot come out the everyday speech. Language is the only way to reach other people. In the Lacan concept, a marker always signifies 
another feature, no word is free from metaphoricity (the metaphor is a sign representing another marker).

Furthermore, Faruk (2012) explains that each word only gets a whole meaning when it ends. In other words, only the last name gives full sense to every word that came before it. Language functions to place oneself in a specific position, become a particular subject. This language function is similar to the part of sitting on a train, where a person's sitting position determines their view of their surroundings.

The author in the Lacanian sense is such a deficient subject. Lacan's theory of the issue is that humans are represented by language, by unique objects called "words". The Lacan technical term for "word" is "marker". Whenever a person speaks or writes, he always manifests himself in language, with markers. Markers are the only way the subject can display it self (Hill, 2002). Likewise, with literature, which is a marker as a manifestation of the author's self.

\section{b. Self and Identity}

Lacan uses the concept of a child standing in front of a mirror as a metaphor. When we look in the mirror, we can never get a closer look at who we are. Is called the "infinity of reflection". According to (Sarup, 2011), another critical Lacanian thought is "the dialectic of confession". This confessional dialectic refers to the idea that we learn who we are from how others behave. Lacan said that one can never achieve a stable image and never feel confident in other's responses. A person does have a view of his identity, but that view has nothing to do with reality. Lacan emphasizes that a person does not have a fixed set of characteristics. A person also never equals any of his attributes. There is no subject except in representation, but no representation can capture the issue in full.

On the one hand, humans are not defined by others as a whole. On the other hand, they can also break free from other people's definitions (Faruk, 2012). Intersubjectivity can never be entirely attained because one can never enter into another's consciousness as a whole.

\section{Previous Study}

This section discusses previous research problems and deals with formal objects and materials with similarities or differences with this research. The first research is "The Analysis of Heathcliff Character in Wuthering Heights by Emily Bronte: A Sigmund Freud's Theory" written by Fabdriah and Zakrimal from Putera Batam University. In this study (Fadriah \& Zakrimal, 2017) analyzed the Heathcliff characters with Sigmund Freud's theoretical approach to determine their id and ego. The results of this study found that Heathcliff has a personality (id) that is rude, irrational, vengeful, and does not believe in God. If in this study used the character's personality traits analysis with the personality theory of Sigmund Freud, which emphasizes the id and ego. This study used Lacan's psychoanalytic theory, which emphasizes understanding the language in literary works to determine the author's unconscious condition reflected in the Mango tree character.

The second research is "Nano Riantiarno's Desire in the Cermin Cinta: A Study of Lacanian Psychoanalysis" written by Ricky Aptifive Manik. In this study (Manik, 2016) analyzed Nano Riantiarno's desire, as reflected in the novel of Cermin Cinta using the metonymy metaphor method. This research found that Nano's desire to be a writer and an artist was made him unconsciously to other symbolic 
signifiants such as writers who "never give up", "resilient", "consistent", "persevere", "diligent", etc. He founded a theater troupe by writing and directing plays. All that he got from the image of Rendra, Putu Wijaya, Arifin C Noor, and Teguh Karya. It is Nano's desire for an ontological wholeness for that identity. "Freedom" becomes an object for Nano to get a jouissance (satisfaction) for himself.

The third is Fina Hiasa's research with the title "Longing for the Real in Novel of Akar by Dee". The research discusses how the author's desire is manifested through the novel of Akar. The connection between Akar's novel, which had a Buddhist background, and Dee's interest in the Buddhist lesson, indicates a relationship between the author's desire and Akar's novel. To answer these indications, the researcher used the Lacan psychoanalysis method, namely through metaphor and metonymy. So that the desire to "be" and "have" the author was found (Hiasa, 2016).

\section{RESEARCH METHOD}

This study used a qualitative research method with a poststructuralism approach using Lacan's psychoanalysis. The research data source is a document, namely the short story of Dengar Keluhan Pohon Mangga by Maria Amin. The sampling technique used purposive sampling or data collection techniques based on specific objectives. In this study, data were obtained from document analysis, and then the data were analyzed according to Lacan's psychoanalytic theory. This study's data analysis technique begins by describing the author's life (Maria Amin) to understand her work. After that, he explained the characters of the characters in the $D K P M$ short story.
Furthermore, the analysis is focused on the short story language, which can be seen through the metaphor and metonymy phenomena in this short story. In this way, it will be seen how the author's subconscious is filled with a sense of lack and loss, so that the desire to cover up the deficiency appears. This desire will encourage humans to find their identity again.

\section{RESULT AND DISCUSSION}

During the Japanese colonial period, the authorship changed from the type of 'new poet' authorship, which was full of rhetoric and superlative to shift to sparing authorship in words. Every word and sentence is carefully weighed before being presented to the reader. Of course, the unstable life in the economic field was also influenced during the Japanese colonial period. One of the authors who was disappointed with Japan was Maria Amin. Her disappointment in seeing the socio-political life made Maria Amin run away into the symbolic world (Rosidi, 2013). This representational narrative style allowed Maria Amin's works to escape Japanese censorship and be published in Panji Pustaka. The allusions to Japan are subtly inserted in symbolic comparisons. However, some of his books that not pass the censorship and then made him a person suspected by the Japanese, one of which is the short story of Dengar Keluhan Pohon Mangga (Jassin, 2013).

$D K P M$ begins by describing a mango tree's beginnings, which starts with planting mango seeds into the ground. From the very beginning of its life, the mango tree suffered greatly. In waiting for a month in the dark earth, he hoped to see the sunshine. However, after he grew up and could see the sun, he was sad and disappointed because right beside him stood a firm areca tree which always mocked him and of course, the areca tree would grow faster 
in reaching the sun. This small and fragile mango tree must grieve every day because of its sad fate and little body and is always defeated and humiliated by the areca tree.

This short story is a short story that has an implied meaning. The author tries to distract the public by expressing what is on his mind, metaphorically. From the title, it appears that this short story expresses an excellent desire for selffulfillment, namely self-recognition. Metaphorically, this short story likens man to a tree and power to the sun. The humans depicted in this short story are in opposition to one another. It can be seen that this short story describes the resistance between two different types of trees, namely the mango tree and the areca tree. Both have other properties. The small mango tree is always oppressed and insulted by the areca tree, while the areca tree is described as a tall, slender, and proud tree. This short story compares metaphorically "Indonesian people" with mango trees and "Japanese people" with areca trees.

From the beginning, this short story shows that the mango tree (the Indonesian nation) is in bad condition so that there is a growing desire and effort to cover up this deficiency continuously. The mango tree wants to find its identity again, become a strong and tall tree, and a recognized tree by others. The existence of the mango tree itself cannot be separated from the involvement of the other, namely humans (the Dutch). With humans negating the mango tree, the mango tree can start its life as an individual or a free subject, as in the following quote.

From human hands, I was put in a hole and backfilled with the earth. After being buried in that dark place, I wanted to look outside. If there was another place, I hoped for bright light.

sun I will reach and attack. Ouch... I'm almost disappointed because I am a slender areca nut next to me, waving its leaves in the wind chewing leaves. The 
visible leaves are mocking me, clapping back and forth, lowly looking at me. Of course..., he will first reach the heavens and greet the Sun Queen of Light.

(Amin, 2013: 134)

In this case, the mango tree is again in poor condition because besides, it has stood a strong and big areca tree, which seems to mock him. After all, he is smaller and weaker. It follows with what Lacan expressed that the human subconscious' condition is always in a state of deficiency, and there are still ways to up these continuous deficiencies.

According to the author's metaphors, $D K P M$ 's short story seems to tell the burden that has been felt Indonesian people after being separated from the Dutch, who had colonized it for three and a half centuries. It can be seen at the beginning of the short story that the beginning of his separation from the Dutch nation was a tough start because the arrival of Japan in Indonesia brought doubts to the Indonesian people. That is, Japan would shed light on the Indonesian people or get a worse fate than the Dutch colonial period. This consideration can be seen in the mango tree monologue below.

For a month, I waited a long time for my heart's desire to cool the sun. For a month, I thought, back and forth, my soul, seeing doubts that I will confirm later. If behind this world my fate remains terrible today ... akh ... indeed this has become my destiny.

(Amin, 2013: 134)

It turned out that the doubts about the mango tree (Indonesian nation) were answered. After the mango tree came out of the dark ground, at once, it saw a tall, slender, and proud areca tree (Japanese). The Japanese have always tortured and insulted the Indonesian people. It can be seen through the following quote about the attitude of the areca tree.

The betel tree, the enemy of my life, always throws its rotten fruit, threatening my life. Once,... almost really hit my young shoots,... fortunately, there is still the fate of a long life.

(Amin, 2013: 135)

Metonymy, this short story, replaces himself (the Indonesian nation) with a mango tree and the Japanese with an areca tree. In this case, the human position as an individual has various kinds of characters replaced by a tree. The replacement of metonymy in parte prototo (part to show the whole) shows that a tree can replace a nation. The diversion changed the meaning of the short story as a whole to avoid the attention of censors in which the prevailing discourse during the Japanese occupation was that works that did not support the Japanese government would not be allowed to be published.

Through these metaphors and metonymy, it can be seen that the short story of $D K P M$ expresses the desire of the Indonesian people (the mango tree) to achieve its existence and gain its integrity and identity.

\section{CONCLUSION}

From the analysis above, the short story of Dengar Keluhan Pohon Mangga by Maria Amin, written during the Japanese colonial period, is a short story that reflects the unconscious condition writer. It can be seen in the $D K P M$ 's short story that the Indonesian nation was expressed metaphorically by using the word "mango tree", the 
Japanese nation as "areca tree", and the Dutch nation as "the man". In this short story, the mango tree (the Indonesian nation) is in a state of deprivation so that there is a desire to gain recognition for its existence as a subject. Lacan's psychoanalytic theory considers that the human subconscious is always in "a lack", so gave rise to a desire to cover up "the lack" and refund its identity.

\section{REFERENCES}

Amin, M. (2013). Dengar Keluhan Pohon Mangga. In H. B. Jassin (Ed.), Kesusasteraan Indonesia di Masa Jepang. Bandung: PT Dunia Pustaka Jaya.

Bracher, M. (2009). Jacques Lacan, Diskursus dan Perubahan Sosial: Pengantar Kritik-Budaya Psikoanalisis. $\quad$ Yogyakarta: Jalasutra.

Fadriah, \& Zakrimal. (2017). The Analysis of Heathcliff Character in Wuthering Heights by Emily Bronte: A Sigmund Freud's Theory. Jurnal Basis. http://ejournal.upbatam.ac.id/ind ex.php/basis/article/view/529

Faruk. (2012). Metode Penelitian Sastra: Sebuah Penjelajahan Awal. Yogyakarta: Pustaka Pelajar.

Hiasa, F. (2016). Kerinduan pada yang Real dalam Novel Akar Karya Dee. Jurnal POETIKA. https://doi.org/10.22146/poetika. 15650

Hill, P. (2002). Lacan untuk Pemula. Yogyakarta: Kanisius.

Jassin, H. B. (2013). Kesusastraan Indonesia di Masa Jepang. Bandung: PT Dunia Pustaka
Jaya.

Manik, R. A. (2016). Hasrat Nano Riantiarno dalam Cermin Cinta: Kajian Psikoanalisis Lacanian. Jurnal POETIKA. https://doi.org/10.22146/poetika. 15492

Ratna, N. K. (2011). Teori, Metode, dan Teknik Penelitian Sastra: dari Strukturalisme hingga Postrukturalisme Perspektif Wacana Naratif. Yogyakarta: Pustaka Pelajar.

Rosidi, A. (2013). Ikhtisar Sejarah Sastera Indonesia. Bandung: Pustaka Jaya.

Sarup, M. (2011). Panduan Pengantar untuk Memahami Postrukturalisme \& Posmodernisme. Yogyakarta: Jalasutra. 